\title{
In Sacco and In Vitro Organic Matter Degradability (OMD) Of Selected Semi Arid Browse Forages
}

\author{
*A.A. Njidda ${ }^{1}$, E. A. Olatunji ${ }^{2}$ and M. G. Garba ${ }^{3}$ \\ ${ }^{1}$ Department of Animal Science, Bayero University, Kano, P.M.B. 3011, Kano State, Nigeria. \\ ${ }^{2}$ Department of Animal Science, University of Abuja, P.M.B. 117, Abuja, Nigeria. \\ ${ }^{3}$ Department of Animal Production and Health, Federal University, Dutsin-Ma, P.M.B. 5001, Katsina State,
}

Nigeria.

\begin{abstract}
Organic matter degradation of Acacia nilotica, Acacia sieberiana, Annana senegalensis, Balanites aegyptiaca, Cassia sieberiana, Combretum leati, Faidhebia albida, Maerua angolensis, Prosopis africana and Vitex doniana using two different techniques: (i) the in sacco nylon bag degradation and in vitro gas production techniques. Samples were incubated in sacco and in vitro for 24, 48, 72 and 96 h. In sacco and in vitro OM degradation kinetics were described using the equation $Y=a+b\left(1-e^{-c t}\right)$. The dry matter $(D M)$ and crude protein (CP) were relatively high ranging from 934.00 to $984.60 \mathrm{~g} \mathrm{Kg}^{-1} \mathrm{DM}$ and 122.50 to $174.80 \mathrm{~g} \mathrm{Kg}^{-1} \mathrm{DM}$ in Cassia sieberiana and Acacis nilotica had the highest value (216.60 and $910.30 \mathrm{~g} \mathrm{Kg}^{-1} \mathrm{DM}$ for as and organic matter $(O M)$ The highest value for neutral detergent fibre (NDF) and acid detergent fibre (ADF) was observed in Vitex doniana. The acid detergent fibre was generally high ranging from 86.40 to $144.70 \mathrm{~g} \mathrm{Kg}^{-1} \mathrm{DM}$. The OM disappearance increases with increasing incubation time in all the browse forages ranging from 28.56 in Balanites aegyptiaca at $24 \mathrm{~h}$ to 76.53 in Combretum leati at $96 \mathrm{~h}$. The OM degradation constant $(a, b, a+b$, lag $T$ and $E D)$ were all significantly different $(P<0.05)$ except ' $c$ ' values. The cumulative gas production was generally low for all the browse forages Acacia sieberiana and Cassia sieberiana having the lowest $(9.66$ $\mathrm{ml} / 200 \mathrm{mg} \mathrm{DM})$ and Vitex doniana having the highest value $(22.66 \mathrm{ml} / 200 \mathrm{mg} \mathrm{DM})$ at $96 \mathrm{~h}$ incubation. In vitro gas production constant showed significant difference $(P<0.05)$ except for rate of constant ' $c$ '. It was concluded that in sacco OM disappearance parameters of browse forages such as the samples used in this study may be predicted from in vitro gas production parameters.

Keywords: browse forages, degradability, gas production, In sacco, In vitro
\end{abstract}

\section{Introduction}

The need to evaluate the nutritional value of fodder trees and shrubs is necessary [1]. Tree and shrub fodder makes important contribution to the protein and energy consumption of browsing ruminants in arid and semi arid regions where forage availability and quality may be severely limited during the dry season $[2,3]$. While it might be assumed that fermentation characteristics of feedstuffs should be evaluated through in vivo trials, it is also obvious that in vivo experiments need a high number of animals, have high financial costs, are difficult to standardize and only the feed to be tested can be fed during trials. Alternatively, in vitro and in situ techniques have been developed to allow its utilization on a routine basis.

The de facto reference method to determine rumen degradability of feed components at various incubation periods is the in situ nylon bag technique (NBT). Applying the equation [4], $\mathrm{P}=\mathrm{a}+\mathrm{b}\left(1-\mathrm{e}^{-\mathrm{ct}}\right)$, to describe the degradation of feeds, the constants, $\mathrm{a}, \mathrm{b}$, and c obtained can also be used to predict feed intake and growth rate [5]. The development of alternative in vitro methods, such as the gas production technique, has lead to the assessment of several mathematical models to describe and interpret the fermentation characteristics of feeds $[6,7]$. While there are enough data to validate gas production models regarding its potential to estimate rumen degradation $[8,9,10]$ a thorough comparison with the nylon bag technique is lacking and few studies have been conducted to compare the prediction capability of the models. Gas production techniques (GPTs) could be a valuable alternative, as a GPT do not measure the same rumen degradation phenomena [11]. Whereas GPT reflects fermentation characteristics of total OM, the NBT only models degradation of the non-washable fraction [12]. Furthermore, comparisons found in literature have been conducted mainly with fibrous feeds and only a limited number of feedstuffs with high proportion of soluble and/or small particles have been studied.

More recently researchers have been investigating the relationship between fermentation kinetics of forages obtained by the in situ nylon bag technique and the in vitro gas production technique $[8,13]$.

The aim of this study was to (i) determine fermentation kinetics of browse forages leaves using the in sacco nylon bag technique and in vitro gas production and (ii) to determine whether it is possible to predict in sacco and in vitro $\mathrm{OM}$ degradability. 


\subsection{Selection of forage samples}

\section{Materials and Methods}

The ten browse species were selected after an initial field survey to evaluate the utilization of multipurpose tree and shrub forages as livestock feed in North-eastern region of Nigeria. The leaf browses were harvested by hand clipping leaves from five branches on twenty mature trees in Maiduguri metropolitan council area of Borno State, Nigeria in the dry season. The forage species were as follows: Acacia nilotica, Acacia sieberiana, Annana senegalensis, Balanites aegyptiaca, Cassia sieberiana, Combretum leati, Faidhebia albida, Maerua angolensis, Prosopis africana and Vitex doniana. Only the leaves and leaf petioles were harvested in order to mimick the parts browsed by goats.

\subsection{Collection and processing of the browse leaves}

The leaves were collected in gunny bags and dried in a shade for 6 days. The leaf browse was then milled through a $2.0 \mathrm{~mm}$ screen for in-vivo digestibility, and a sub sample taken and milled further through $1.0 \mathrm{~mm}$ screen for use in gas production trial and proximate analysis.

\subsection{In sacco degradation}

Duplicate nylon bags (bag size, $80 \mathrm{mmx} 140 \mathrm{~mm}$; pore size $45 \mu \mathrm{m}$ ) containing $5 \mathrm{~g}$ of milled dry sample were weighed and then incubated in the rumen of two fistulated Friesian steers 23 months old and weighing 540 $\mathrm{kg}$. The bags were then withdrawn after 3, 6, 12, 24, 48, 72 and 96 hours. The zero hour was obtained by soaking the bags in a water bath maintained at $39^{\circ} \mathrm{C}$ for 1 hour. After the incubation period, the bags were withdrawn then hand washed under running tap water until the water coming out of the bags was clear. The washed bags and contents were then dried for 48 hours at $60^{\circ} \mathrm{C}$ in a draught oven to determine DM disappearance. The disappearance values were fitted in the equation [4]:

$\mathrm{P}=\mathrm{a}+\mathrm{b}\left(1-\mathrm{e}^{-\mathrm{ct}}\right)$

Where

$\mathrm{P} \quad=\quad$ Potential degradability after time' $\mathrm{t}$ '

a $\quad=\quad$ Water Soluble Fraction (zero hour)

$\mathrm{b}=$ Insoluble but degradable fraction after time ' $\mathrm{t}$ '

$\mathrm{c} \quad=\quad$ Rate of degradation of slowly degradable fraction $\mathrm{b}$

$\mathrm{t}=$ Incubation length i.e. $3,6,12,24,36,48,72,84$ and 96 hours

e $\quad=\quad$ exponential

\subsection{In-vitro gas production}

The gas production technique [14] was used in the in-vitro gas production assessment. The net gas volumes data was then fitted in the equation [15]:

$\mathrm{Y}=\mathrm{a}+\mathrm{b}\left(1-\mathrm{e}^{-\mathrm{ct}}\right)$

Where:

$\mathrm{Y}=$ the volume of gas produced $(\mathrm{ml})$ at time $\mathrm{t}$,

$\mathrm{a}=$ the gas production from the immediately soluble fraction $(\mathrm{ml})$,

$\mathrm{b}=$ the gas production from the insoluble but degradable fraction $(\mathrm{ml})$,

$\mathrm{a}+\mathrm{b}=$ the potential gas production $(\mathrm{ml})$,

$\mathrm{c}=$ the rate constant of gas production (fraction $/ \mathrm{h}$ )

$\mathrm{t}=$ gas production intervals i.e. $3,6,12,24,36,48,72,84$ and 96 hours

OMD96 $\mathrm{h}=$ organic matter digestibility at 96 hours.

In-vitro organic matter digestibility was calculated from the equation: OMD $(\%)=18.53+0.9239$ gas production (at $48 \mathrm{hrs})+0.0540 \mathrm{CP}[14]$.

\subsection{Chemical analysis}

The proximate composition including dry matter (DM), organic matter $(\mathrm{OM})$ and total nitrogen $(\mathrm{N})$ were determined following standard methods of AOAC [16] and $\mathrm{CP}$ was calculated as $\mathrm{N} \times$ 6.25. Neutral detergent fibre (NDF), acid detergent fibre (ADF) and acid detergent lignin (ADL) were determined by the method [17]. Organic matter (OM) was determined by subtracting ash from dry matter (DM).

\subsection{Statistical analysis}

Data obtained was subjected to analysis of variance. Where significant differences occurred, the means will be separated using Duncan multiple range F-test [18] options. 


\subsection{Chemical composition of the browse forages}

\section{Results}

The chemical composition of the browse forage leaves determined in this study is presented in Table 1. Dry matter content ranged from $934.00 \mathrm{~g} \mathrm{~kg}^{-1} \mathrm{DM}$ in Prosopis africana to $984.60 \mathrm{~g} \mathrm{~kg}^{-1}$ in Acacia sieberiana on DM basis. On the average the dry matter content of the browse leaves in this study was $956.31 \mathrm{~g} \mathrm{~kg}^{-1} \mathrm{DM}$. Generally, the examined plant leaves had high crude protein values. The mean content of this nutrient was $156.95 \mathrm{~g} \mathrm{~kg}^{-1} \mathrm{DM}^{-1}$ ranging from a low value of $122.50 \mathrm{~g} \mathrm{~kg}^{-1} \mathrm{DM}$ in Cassia sieberiana to $181.80 \mathrm{~g} \mathrm{~kg}^{-1} \mathrm{DM}$ in Vitex doniana. Ash content of the browse forages range from $70.60 \mathrm{~g} \mathrm{~kg}^{-1} \mathrm{DM}$ in Acacia nilotica to $216.60 \mathrm{~g} \mathrm{~kg}^{-1} \mathrm{DM}$ in Cassia sieberiana. Values obtained for organic matter content of the browse forages ranged from $761.30 \%$ in Balanite aegyptiaca to $910.30 \mathrm{~g} \mathrm{~kg}^{-1} \mathrm{DM}$ in Acacia nilotica with a mean of $836.60 \mathrm{~g} \mathrm{~kg}^{-1} \mathrm{DM}$. The highest neutral detergent fibre content of $590.20 \mathrm{~g} \mathrm{~kg}^{-1} \mathrm{DM}$ was recorded in Vitex donia while Annana senegalensis had the lowest value of $493.10 \mathrm{~g} \mathrm{~kg}^{-1} \mathrm{DM}$. The acid detergent fibre levels in the experimental leaves ranged from $200.50 \mathrm{~g} \mathrm{~kg}^{-1} \mathrm{DM}^{\text {in }}$ Balanites aeegyptiaca to $265.50 \mathrm{~g} \mathrm{~kg}^{-1} \mathrm{DM}$ in Vitex doniana. The least lignin content of $86.40 \mathrm{~g} \mathrm{~kg}^{-1} \mathrm{DM}$ in the browse forages was recorded in Prosopis africana while Acacia sieberiana had the highest value of $169.00 \mathrm{~g} \mathrm{~kg}^{-1}$ DM. Condensed tannin varied from $0.09 \mathrm{mg} / \mathrm{g}$ DM in Acacia sieberiana and Vitex doniana to $0.41 \mathrm{mg} / \mathrm{g} \mathrm{DM}$ in Maerua angolensis.

Table 1: Chemical composition of selected semi arid browse species $\left(\mathrm{g} \mathrm{kg}^{-1} \mathrm{DM}\right)$

\begin{tabular}{lcccccccl}
\hline & DM & CP & Ash & OM & NDF & ADF & ADL & CT \\
\hline Acacia nilotica & $981.00^{\mathrm{b}}$ & $157.00^{\mathrm{c}}$ & $70.60^{\mathrm{h}}$ & $910.30^{\mathrm{a}}$ & $586.30^{\mathrm{b}}$ & $253.30^{\mathrm{b}}$ & $109.50^{\mathrm{f}}$ & $0.12^{\mathrm{g}}$ \\
Acacia sieberiana & $984.60^{\mathrm{a}}$ & $156.00^{\mathrm{c}}$ & $111.00^{\mathrm{f}}$ & $873.60^{\mathrm{c}}$ & $580.50^{\mathrm{c}}$ & $253.80^{\mathrm{b}}$ & $169.00^{\mathrm{d}}$ & $0.09 \mathrm{i}$ \\
Annana senegalensis & $959.30^{\mathrm{e}}$ & $158.20^{\mathrm{c}}$ & $86.30^{\mathrm{g}}$ & $856.30^{\mathrm{d}}$ & $493.10^{\mathrm{i}}$ & $222.90^{\mathrm{f}}$ & $89.30^{\mathrm{h}}$ & $0.17^{\mathrm{e}}$ \\
Balanites aegyptiaca & $942.00^{\mathrm{g}}$ & $174.80^{\mathrm{b}}$ & $180.60^{\mathrm{b}}$ & $761.30^{\mathrm{h}}$ & $528.80^{\mathrm{h}}$ & $200.50^{\mathrm{i}}$ & $108.90^{\mathrm{f}}$ & $0.23^{\mathrm{c}}$ \\
Cassia sieberiana $^{\mathrm{f}}$ & $953.00^{\mathrm{f}}$ & $122.50^{\mathrm{f}}$ & $216.60^{\mathrm{a}}$ & $803.00^{\mathrm{f}}$ & $531.00^{\mathrm{g}}$ & $218.50^{\mathrm{h}}$ & $116.80^{\mathrm{d}}$ & $0.21^{\mathrm{d}}$ \\
Combretum leati & $978.00^{\mathrm{c}}$ & $135.40^{\mathrm{e}}$ & $121.30^{\mathrm{d}}$ & $856.70^{\mathrm{d}}$ & $567.70^{\mathrm{e}}$ & $221.80^{\mathrm{g}}$ & $112.80^{\mathrm{e}}$ & $0.10^{\mathrm{h}}$ \\
Faidhebia albida & $964.60^{\mathrm{d}}$ & $159.30^{\mathrm{c}}$ & $71.60^{\mathrm{h}}$ & $893.00^{\mathrm{b}}$ & $574.80^{\mathrm{d}}$ & $234.80^{\mathrm{c}}$ & $135.50^{\mathrm{c}}$ & $0.40^{\mathrm{b}}$ \\
Maerua angolensis & $922.60^{\mathrm{i}}$ & $174.30^{\mathrm{b}}$ & $154.30^{\mathrm{c}}$ & $767.60^{\mathrm{g}}$ & $586.70^{\mathrm{b}}$ & $228.90^{\mathrm{d}}$ & $144.70^{\mathrm{b}}$ & $0.41^{\mathrm{a}}$ \\
Prosopis Africana & $934.00^{\mathrm{h}}$ & $150.20^{\mathrm{d}}$ & $117.30^{\mathrm{e}}$ & $816.60^{\mathrm{e}}$ & $559.10^{\mathrm{f}}$ & $227.60^{\mathrm{e}}$ & $86.40^{\mathrm{i}}$ & $0.15^{\mathrm{f}}$ \\
Vitex doniana & $944.00^{\mathrm{g}}$ & $181.80^{\mathrm{a}}$ & $121.60^{\mathrm{d}}$ & $822.30^{\mathrm{e}}$ & $590.20^{\mathrm{a}}$ & $265.50^{\mathrm{a}}$ & $91.00^{\mathrm{g}}$ & $0.09^{\mathrm{i}}$ \\
\hline MEAN & $\mathbf{9 5 6 . 3 1}$ & $\mathbf{1 5 6 . 9 5}$ & $\mathbf{1 2 5 . 1 2}$ & $\mathbf{8 3 6 . 1 0}$ & $\mathbf{5 5 9 . 8 2}$ & $\mathbf{2 3 2 . 7 6}$ & $\mathbf{1 1 6 . 3 9}$ & $\mathbf{0 . 1 9}$ \\
SEM & $\mathbf{2 . 3 2}$ & $\mathbf{3 . 2 2}$ & $\mathbf{2 . 7 2}$ & $\mathbf{3 . 0 6}$ & $\mathbf{0 . 9 6}$ & $\mathbf{0 . 3 3}$ & $\mathbf{0 . 5 9}$ & $\mathbf{0 . 0 2}$ \\
\hline
\end{tabular}

$\mathrm{a}, \mathrm{b}, \mathrm{c}, \mathrm{d}=$ mean values along the same column with different superscripts are significantly different $(\mathrm{P}<0.05)$;

$\mathrm{NDF}=$ Neutral detergent fibre; $\mathrm{ADF}=$ Acid detergent fibre; Acid detergent lignin; $\mathrm{CT}=\mathrm{Condensed} \mathrm{Tannin;}$

$\mathrm{SEM}=$ Standard error of means.

\subsection{Organic Matter (OM) disappearance}

The extent of disappearance of OM in the incubated browse leaves is shown in Table 2. Organic matter content was highly degradable though it progressed slowly from 24 hour with a mean of 35.40 to 96 hours with a mean of $74.64 \%$. The least value for OM disappearance from the leaves incubated was recorded in Balanite aegytiaca at $28.56 \%$ though the OM disappearance were generally low for all the browse forages at hours incubation periods. Acacia nilotica had the highest OM disappearance of $75.90 \%$.

\subsection{Organic matter (OM) degradation parameters}

Organic matter degradation characteristics for the incubated browse leaves are shown in Table 2. Except for rate of degradation ' $c$ ' which was not significant, all other characteristics varied significantly $(\mathrm{P}<0.05)$. Values obtained for the solubility of $\mathrm{OM}$ in browse leaves ranged from a low value of $2.23 \%$ in Maerua angolensis to a high value of $15.33 \%$ in Faidhebia albida. With the insoluble but degradable fraction ' $b$ ', OM recorded the least value in Acacia nilotica (39.22\%) while the highest was in Balanite aegytiaca with $73.44 \%$. No significant differences $(\mathrm{P}>0.05)$ were observed for degradation rate constant between the leaves studied. However, a range of $0.013 / \mathrm{hr}$ in Balanite aegytiaca and Cassia sieberiana to $0.138 / \mathrm{hr}$ in Acacia nilotica was observed. At an outflow rate of 0.12 , the effective degradability of OM was highest in Acacia nilotica (29.60\%) and lowest in Prosopis africana (16.30\%).

\subsection{In vitro gas production}

The in vitro cumulative gas production after $96 \mathrm{~h}$, potential gas production (asymptotics gas production; fraction b), and rate of gas production (fraction c) of the browse forges are presented in Table 3 . The forages significantly $(\mathrm{P}<0.05)$ differ in the gas production and fermentation characteristics. Vitex doniana 
produced the highest gas production $(22.66 \mathrm{ml} / 200 \mathrm{mg} \mathrm{DM})$ throughout the incubation period at $96 \mathrm{~h}$ while Acacia sieberiana and Cassia sieberiana produced the least gas volume of $9.66 \mathrm{ml} / 200 \mathrm{mg}$ DM at $96 \mathrm{~h}$.

Table 2. In sacco organic matter (OM) Disappearance and degradation constants of semi-arid browse species (\% DM)

\begin{tabular}{|c|c|c|c|c|c|c|c|c|c|c|c|}
\hline \multirow{2}{*}{$\begin{array}{l}\text { Drowse forages } \\
\text { Bug }\end{array}$} & \multirow[b]{2}{*}{24} & \multicolumn{3}{|c|}{ In vitro gas production } & \multicolumn{7}{|c|}{ In vitro gas production parameters } \\
\hline & & 48 & 72 & 96 & a & B & $a+b$ & c & $\mathrm{T}$ & $\mathrm{Y}$ & OMD $96(\%)$ \\
\hline Acacia nilotica & $11.33^{b}$ & $12.33^{\circ}$ & $12.33^{\mathrm{d}}$ & $12.33^{\mathrm{d}}$ & $5.33^{\mathrm{a}}$ & $7.00 \mathrm{fg}$ & $12.33^{\circ}$ & 0.072 & $8.00 \Omega$ & $8.33^{b}$ & $34.84^{f}$ \\
\hline Acacia sieberiana & $7.66^{\circledR}$ & $9.66^{\mathrm{cd}}$ & $9.66^{f}$ & $9.66=$ & $2.00^{\circ}$ & $7.67 \mathrm{fg}$ & $9.67 z$ & 0.022 & $5.33^{h}$ & $6.00^{\circ}$ & $35.05^{\mathrm{e}}$ \\
\hline Annona senegalonsis. & $8.00^{d}$ & $11.00^{\circ}$ & $11.66^{\mathrm{d}}$ & $11.66^{\mathrm{d}}$ & $1.33^{\mathrm{d}}$ & $11.00^{\mathrm{e}}$ & $12.33^{\mathrm{e}}$ & 0.046 & $18.00^{\circ}$ & $6.67^{\circ}$ & $35.32^{2}$ \\
\hline Balanites arguptiaca & $5.00^{f}$ & $12.66^{\circ}$ & $18.66^{\circ}$ & $19.66^{b}$ & $1.33^{d}$ & $18.33^{b c}$ & $19.67^{\circ}$ & 0.017 & $22.00^{\mathrm{a}}$ & $5.33^{\mathrm{de}}$ & $49.31^{b}$ \\
\hline Cassia sieberiang & $7.00^{\mathrm{a}}$ & $9.66^{\mathrm{cd}}$ & $9.66^{f}$ & $9.66^{\circ}$ & $1.33^{\mathrm{d}}$ & $9.00^{f}$ & $10.33^{f}$ & 0.046 & $20.00^{b}$ & $6.67^{\circ}$ & $40.41^{d}$ \\
\hline Combretum leati & $10.66^{b c}$ & $14.66^{\circ}$ & $15.66^{\circ}$ & $15.66^{\circ}$ & $2.33^{\circ}$ & $13.33^{\mathrm{d}}$ & $15.67^{d}$ & 0.043 & $15.00^{d}$ & $8.67^{b}$ & $40.12^{d}$ \\
\hline Eaidhebia albida & $8.33^{\mathrm{d}}$ & $10.66^{\circ}$ & $10.66^{d}$ & $10.66^{\mathrm{d}}$ & $2.00^{\circ}$ & $8.67^{f}$ & $10.67^{f}$ & 0.050 & $13.00^{\mathrm{e}}$ & $5.33^{d}$ & $33.52 \Xi$ \\
\hline Marua angolonsis. & $13.66^{\mathrm{a}}$ & $18.66^{\mathrm{a}}$ & $21.33^{\mathrm{a}}$ & $21.33^{\mathrm{a}}$ & $2.33^{\circ}$ & $19.00^{b}$ & $21.33^{b}$ & 0.040 & $10.00^{f}$ & $8.33^{\circ}$ & $49.06^{\circ}$ \\
\hline Prosopis Africana & $8.00^{d}$ & $9.33 \mathrm{~cd}$ & $10.33^{d}$ & $10.33^{d}$ & $2.33^{\circ}$ & $8.00^{f}$ & $10.33^{f}$ & 0.054 & $11.00^{f}$ & $5.67^{d}$ & $98.02^{\mathrm{a}}$ \\
\hline Vitex doniang & $13.66^{\mathrm{a}}$ & $17.33^{\mathrm{a}}$ & $22.66^{\mathrm{a}}$ & $22.66^{\mathrm{a}}$ & $3.00^{\mathrm{a}}$ & $20.67^{\mathrm{a}}$ & $23.67^{\mathrm{a}}$ & 0.043 & $18.00^{\circ}$ & $12.67^{\mathrm{a}}$ & $46.68^{\circ}$ \\
\hline MEAN & 9.33 & 11.70 & 14.26 & 14.36 & 2.33 & 12.27 & 14.60 & 0.043 & 14.03 & 8.57 & 46.23 \\
\hline SEM & 1.52 & 2.24 & 2.49 & 2.33 & 0.96 & 1.22 & 1.23 & 0.003 & 1.28 & 1.06 & 0.76 \\
\hline
\end{tabular}

a, b, c, means in the same column with different superscript differ significantly $(\mathrm{P}<0.05)$; SEM=Standard error means; NS=Not Significant

Table 3. In vitro gas production ( $\mathrm{ml} / 200 \mathrm{mg}$ DM), production constant and (OMD (\%) of selected semiarid browses species

\begin{tabular}{|c|c|c|c|c|c|c|c|c|c|c|c|}
\hline \multirow{2}{*}{$\begin{array}{l} \\
\text { Browse forages }\end{array}$} & \multirow[b]{2}{*}{24} & \multicolumn{3}{|c|}{ In vitro gas production } & \multicolumn{7}{|c|}{ In vitro gas production parameters } \\
\hline & & 48 & 72 & 96 & a & B & $a+b$ & $\mathrm{c}$ & $\mathrm{T}$ & $\mathrm{Y}$ & OMD $96(\%)$ \\
\hline Acacia nilotica & $11.33^{\circ}$ & $12.3^{\circ}$ & $12.33^{\mathrm{d}}$ & $12.33^{\mathrm{d}}$ & $5.33^{\mathrm{a}}$ & $7.00^{\mathrm{fg}}$ & $12.33^{\circ}$ & 0.072 & $8.00 \mathrm{~s}$ & $8.33^{\circ}$ & $34.84^{f}$ \\
\hline Acacia sieberiana & $7.66^{:}$ & $9.66^{\mathrm{cd}}$ & $9.66^{i}$ & $9.66^{:}$ & $2.00^{\mathrm{c}}$ & $7.67 \mathrm{fg}$ & $9.67 \AA$ & 0.022 & $5.33^{\mathrm{h}}$ & $6.00^{\circ}$ & $35.05^{\circ}$ \\
\hline Annana senegalensis & $8.00^{d}$ & $11.00^{\circ}$ & $11.66^{\mathrm{d}}$ & $11.66^{\mathrm{d}}$ & $1.33^{\mathrm{d}}$ & $11.00^{\circ}$ & $12.33^{\mathrm{a}}$ & 0.046 & $18.00^{\circ}$ & $6.67^{\mathrm{c}}$ & $35.32^{2}$ \\
\hline Balanites aeguptiaca & $5.00^{\AA}$ & $12.66^{\circ}$ & $18.66^{\circ}$ & $19.66^{\circ}$ & $1.33^{\mathrm{d}}$ & $18.33^{b c}$ & $19.67^{\circ}$ & 0.017 & $22.00^{\mathrm{a}}$ & $5.33^{\mathrm{de}}$ & $49.31^{b}$ \\
\hline Cassia sieberiang & $7.00^{\circ}$ & $9.66^{\mathrm{cd}}$ & $9.66^{f}$ & $9.66^{\circ}$ & $1.33^{d}$ & $9.00^{f}$ & $10.33^{f}$ & 0.046 & $20.00^{\circ}$ & $6.677^{\circ}$ & $40.41^{\mathrm{d}}$ \\
\hline Combretum leati & $10.66^{\circ \mathrm{c}}$ & $14.66^{\circ}$ & $15.66^{\circ}$ & $15.66^{\circ}$ & $2.33 \mathrm{c}$ & $13.33^{\mathrm{d}}$ & $15.67^{\mathrm{d}}$ & 0.043 & $15.00^{\mathrm{d}}$ & $8.67^{\circ}$ & $40.12^{\mathrm{d}}$ \\
\hline Faidhebig albidg & $8.33^{\mathrm{d}}$ & $10.66^{\circ}$ & $10.66^{\mathrm{d}}$ & $10.66^{\mathrm{d}}$ & $2.00^{\circ}$ & $8.67^{i}$ & $10.67^{t}$ & 0.050 & $13.00^{\mathrm{s}}$ & $5.33^{\mathrm{d}}$ & $33.52 \Xi$ \\
\hline Marna angolensis. & $13.66^{\mathrm{s}}$ & $18.66^{\mathrm{s}}$ & $21.33^{\mathrm{a}}$ & $21.33^{\mathrm{a}}$ & $2.33^{\circ}$ & $19.00^{\circ}$ & $21.33^{b}$ & 0.040 & $10.00^{f}$ & $8.33^{\circ}$ & $49.06^{\circ}$ \\
\hline Prosopis Africana & $8.00^{d}$ & $9.33^{\mathrm{cd}}$ & $10.33^{\mathrm{d}}$ & $10.33^{\mathrm{d}}$ & $2.33^{\mathrm{c}}$ & $8.00^{\mathrm{f}}$ & $10.33^{f}$ & 0.054 & $11.00^{f}$ & $5.67^{d}$ & $98.02^{\mathrm{a}}$ \\
\hline Vitex doniang & $13.66^{\mathrm{a}}$ & $17.33^{\mathrm{a}}$ & $22.66^{\mathrm{s}}$ & $22.66^{\mathrm{a}}$ & $3.00^{\mathrm{a}}$ & $20.67^{\mathrm{a}}$ & $23.67^{\mathrm{a}}$ & 0.043 & $18.00^{\circ}$ & $12.67^{\mathrm{s}}$ & $46.68^{\circ}$ \\
\hline MEAN & 9.33 & 11.70 & 14.26 & 14.36 & 2.33 & 12.27 & 14.60 & 0.043 & 14.03 & 8.57 & 46.23 \\
\hline SEMI & 1.52 & 2.24 & 2.49 & 2.33 & 0.96 & 1.22 & 1.23 & 0.003 & 1.28 & 1.06 & 0.76 \\
\hline
\end{tabular}

$a, b, c, d=$ mean values along the same column with different superscripts are significantly different $(\mathrm{P}<0.05)$; $\mathrm{SEM}=$ Standard error means; Organic matter digestibility $(\mathrm{OMD}=\%)$

\subsection{In vitro organic matter degradability}

Organic Matter Digestibility (OMD) ranged from 33.52 in Faidhebia albida to 98.02 in Prosopis Africana. Generally all values for OM are below 50\% except for Prosopis africana.

\section{Discussion}

The crude protein (CP) content of the browse forages studied was generally higher. which is above the $7 \% \mathrm{CP}$ requirement for ruminants that should provide ammonia required by rumen microorganism to support optimum microbial growth. The use of browse forages in small quantities in order to supplement poor quality pastures and crop residues has been justified [19]. The high CP content of browse species is well documented and is one of the main distinctive characteristic of browse compared to most grasses. A range of CP contents from 12 to 30\% for tropical tree legumes have been reported [20], and Le Houerou [21] gave a mean of 12.5\% in West African browse species with about $17 \%$ for leguminous species. Generally, the $\mathrm{CP}$ content in browse has been shown to be above the minimum level required (7\%) for microbial activities in the rumen [20]. The species in the leguminosae family have a higher protein content compared to other species, although species in the Capparidaceae family have on average $25 \%$ more protein than legumes [21]. Le Houerou [21] also noted that all browse species are able at all their phenological stages to meet the energy requirements of livestock at maintenance level and often well above, and thus West African browse are considered to be excellent fodder, 
with very few exceptions. The difference in $\mathrm{CP}$ content between species can be explained by inherent characteristics of each species related to the ability to extract and accumulate nutrients from soil and/or to fix atmospheric nitrogen, which is the case for legumes plants. The other factors causing variation in the chemical composition of browse forages include soil type (location), the plant part (leaf, stem, pod), age of leaf and season. With regard to the location, some authors have reported that browse plants in the Sahelian zone are higher in $\mathrm{N}$ compared to plants in the humid zone [22]. Younger leaves are richer in $\mathrm{N}$ than mature leaves, which however contain more $\mathrm{N}$ than the latter. The fruits are shown to have a $\mathrm{N}$ content in between young and old leaves, and vary little with stage of maturity [23].

With regard to fibre content similar mean for NDF and lignin contents across different ecological zones as follows $40.1 \%$ and $11.7 \%$ in the Sahelian zone, $45.7 \%$ and $10.5 \%$ in the sub-humid zone and $43.6 \%$ and $9.3 \%$ in the humid zone respectively [22]. A range of 31 to $57 \%$ for NDF and 19 to $43 \%$ for ADF have been reported [24]. The values of the present study fall within the range reported by Njidda et al. [25]. NDF and ADF contents in the browse forages studied were generally higher compare to the values reported by Njidda [26] and this can limit feed intake [27]. This species also had high lignin content. Lignin is a component of the cell wall, and deposited as part of the cell wall-thickening process [28]. Lignin is in general higher in browse than in herbaceous plants. The content varies according to species, age and the plant parts. Positive correlations were reported between contents of lignin and soluble or insoluble proanthocyanidins [22]. A negative correlation between the content of NDF and soluble phenolics and positive correlation with insoluble proanthocyanidins was observed [29]. The browse forages had moderate to high content of fibre. This is a positive attribute of the browse forages since the voluntary DM intake and digestibility are dependent on the cell wall constituents (fibre), especially the NDF and lignin [30]. Tannins are phenolic plant secondary compounds and are widely distributed through the plant kingdom, especially legumes and browses which affect animal performance in many countries [31]. The level of CT is lower than the range of 60 to $100 \mathrm{~g} \mathrm{Kg}^{-1} \mathrm{DM}$ considered depressing feed intake and growth [32] but within the range 0.41 to $0.81 \mathrm{mg} \mathrm{g}^{-1} \mathrm{DM}$ reported by Njidda et al. [25] for semi arid browse forages.

Organic matter disappearance from the incubated test leaves was high at $96 \mathrm{~h}$ incubation period. The highest $48 \mathrm{hrs}$ disappearance value of $52.98 \%$ was obtained for Faidhebia albida suggesting that the organic matter in this plant was the most degraded. In this same period, about $45 \%$ of the organic matter in the browse leaves had been lost.

Determining the degradation of organic matter in situ is essential. This is in view of the fact that microbial protein synthesis is highly dependent on availability of rumen degradable organic matter [33] are of the view that rate of nitrogen and carbohydrate degradation especially from forage and concentrate mixtures, increase the efficiency of microbial protein synthesis due to improved rumen environment for the growth of more diverse bacteria species. The shrub and tree leaves used in this study varied in organic matter degradation characteristics,

Readily soluble fraction of organic matter in the test leaves was observed to be highest $16.12 \%$ in both Cassia sieberiana.This may be due to the presence of degradable carbohydrates, particularly the non-structural ones and NDF proteins and fat, components that may make organic matter readily degradable in situ in the rumen [34]. In this regard, feeding diets with at least $12 \%$ protein may be necessary to maximize organic matter fermentation in the rumen [35]. On the contrary the least 'a' value recorded in Maerua angolensis indicates that this browse forage may be composed of slow degrading carbohydrates, likely to affect the efficiency of microbial protein synthesis [36]. Nevertheless, the organic matter solubility range reported in the shrub and tree leaves of this of this study (2.23 to $16.12 \%$ ) were within the range reported in some roughage [34].

The insoluble but degradable organic matter frraction ' $b$ ' was high in the plant leaves compared to values reported for some multipurpose tree species [37]. This may be the result of the organic matter solubility in the leaves indicating the possibility of a high amount of nutrients by-passing the rumen microbes.

The potential degradability ' $a+b$ ' of the organic matter in the leaves studied was generally high and reflected the high soluble ('a') organic matter fraction in the leaves. This may have been due to the low rate of degradation constant ' $c$ ' as [38] with the potential degradability of dry matter in browse plants. Potential degradability values reported for roughages [34] were similar to what obtained in this investigation. Effective degradability values reported for organic matter in the leaves studied showed this nutrient to be well degraded in situ at an outflow value of 0.12 . However, it was observed that variations in effective degradability amongst leaves to be associated with variability within the leaves [39].

The results of the gas production and fermentation characteristics of the browse forages are presented in Table 3. Gas production parameters suggested differences in nutritional value that were generally closely related to chemical composition [40]. The values are within the range reported earlier for browse forages from Nigeria [41]. Chemical composition and in vitro fermentation and digestibility are largely affected by plant species, plant morphological fraction, environmental factors, and stage of maturity [42, 43]. These factors influence the amount of substrate OM that is fermented and the short chain fatty acids (SCFAs) produced upon 
fermentation. This is because gas production results from fermentation of the feed $\mathrm{OM}$ and $\mathrm{CO}_{2}$ produced from the buffering of the SCFAs by the bicarbonate buffer. Cell wall content (NDF and ADF) were negatively correlated with gas production at all incubation times and estimated parameters. This may tend to reduce the microbial growth and enzyme activity [44] or intestinal bacterial activity [45]. A decrease in rate and extent of gas production of some shrubs due to their high contents of lignin and tannins through increasing the adverse environmental conditions as incubation time progressed was observed [46]. This is consistent with De Boever et al. [47] who reported that gas production was negatively related to NDF content and positively with starch. Also, the relatively high level of ADL in browse forages as shown in Table 1 explained in part the limited in vitro degradation and therefore the lower amount of gas produced. Similar observations were reported by Nordheim-Viken and Volden, [48, 49]. McAllister et al. [50] also observe that higher NDF and lignifications and/or higher $\mathrm{ADF} / \mathrm{NDF}$ proportion and free-CT contents can reduce attachment of ruminal microbes to feed particles, as well as inhibit microbial growth and enzyme activity [44] or intestinal bacterial activity [46] by free-condensed tannins and hence lead to lower gas production.

However, since gas production on incubation of feeds in buffered rumen fluid is associated with feed fermentation, and carbohydrate fractions, the low gas production from Acacia sieberiana and Cassia sieberiana and other browse forages characterized with low gas production could be related to low feeding value of these feeds. These browse forages contains more than $40 \%$ of its dry matter in the form of cellulose and hemicellulose but its degradability is very low. One of the main reasons for this low degradability is the presence of lignin which protects carbohydrates from attack by rumen microbes. Incubation of feedstuff with buffered rumen fluid in vitro, the carbohydrates are fermented to short chain fatty acids (SCFA), gases, mainly $\mathrm{CO}_{2}$ and $\mathrm{CH}_{4}$, and microbial cells. Gas production is basically the result of fermentation of carbohydrates to acetate, propionate and butyrate [51] and substantial changes in carbohydrate fractions were reflected by total gas produced [52]. Gas production from protein fermentation is relatively small as compared to carbohydrate fermentation while, contribution of fat to gas production is negligible [53]. However, some other prospective and novel plant genera with desirable agronomic and nutritive profiles, such as Acacia, [54], had potent inhibitory effects on gas production and VFA. Other researchers have reported similar findings with plants that are known to contain plant secondary compound (PSC) that can affect rumen microbes when examined in vitro [55]. While legumes are reported to contain tannins that can reduce fermentation parameters [55] for others, such as the genus Leptadenia, the effect may be related to different classes of bioactive PSC [56].

Kinetics of gas production obtained from the exponential model is presented in Table 2. Both rate constants $b$ and $c$ showed significant differences among browse forages. Similarly, the extent $(a+b)$ of gas volumes was higher for Vitex doniana than for trees. Khazaal et al. [57] indicated that the intake of a feed is mostly explained by the rate of gas production (c) which affects the rate of passage of the feed through the rumen, whereas the potential gas production $(a+b)$, is associated with the degradability of the feed. Thus, the higher values obtained for the $(c)$ and $(a+b)$ parameters in the browse forages, may indicate a better nutrient availability for rumen micro organisms in animals grazing such vegetative species in semi-arid areas.

\section{Conclusion}

Base on the findings, comparative values for OMD shows higher values for in sacco technique when compared to in vitro technique, the browse forages can also serve as supplement because of the high protein content. The in sacco and in vitro gas production parameters, particularly the fermentation characteristics is a potential way to evaluate the nutritional quality of forages consumed by grazing ruminants.

\section{References}

[1] Nherera, F. V., Ndlovu, N. R. And Dzowela, B.H. (1999). Relationships between in vitro gas production characteristics, chemical composition and in vitro quality measurements in goats fed tree fodder supplements. Small Ruminant Research, 31: 117-126.

[2] Papachristou, T. G. (1996). Intake, digestibility and nutrient utilization of oriental hornbeam and ash browse by goats and sheep. Small Ruminant Research 23: 91-98

[3] Degen, A. A., Blanke, A., Becker, K., Kam, M., Benjamin, R. W. And Makkar, H. P. S. (1997). The nutritive value of Acacia saligna and Acacia saligna for goats and sheep. Animal Science, 64, 253-259.

[4] McDonald, I. (1981). A revised model for the estimation of protein degradability in the rumen. Journal of Agricultural Science (Cambridge) 96, 251-252.

[5] Ørskov, E.R., Reid, G. W. and Kay, M. (1988). Prediction of intake by cattle from degradation characteristics of roughages. Animal Production. 46:29-34

[6] France, J., Dijkstra, J., Dhanoa, M. S., Lopez, S., and Bannink, A. (2000). Estimating the extent of degradation of ruminant feeds from a description of their gas production profiles observed in vitro: derivation of models and other mathematical considerations. British Journal of Nutrition, 83, 43-150.

[7] Calabro, S., Lopez, S., Piccolo, V., Dijkstra, J., Dhanoa, M.S., France, J., (2005). Comparative analysis of gas production profiles obtained with buffalo and sheep ruminal fluid as the source of inoculum. Animal Feed Science and Technology 123 (124), 51-65.

[8] Khazaal, K., Denthino, M.T., Ribeiro, J.M. and Ørskov, E.R. (1993). A comparison of gas production during incubation with rumen contents in vitro and nylon bag degradability as predictors of apparent digestibility in vitro and voluntary intake of hays. Animal Production 57, 105-112. 
[9] Lopez, S., Carro, M.D., Gonzales, J.S., Ovejero, F.J., (1998). Comparison of different in vitro and in situ methods to estimate the extent and rate of degradation of hays in the rumen. Animal Feed Science and Technology 73, 99-113.

[10] Cone J.W., Van Gelder A.H., Soliman I.A., De Visser H. and Van Vuuren A.M. (1999): Different techniques to study rumen fermentation characteristics of maturing grass and grass silage. Journal of Dairy Science, 82, 957-966.

[11] Valentine, S. F., Williams, P. E. V., Forbes, J. M. and Sauvant, D. (1999). Comparison of the in vitro gas production technique and nylon bag degradability technique to measure short - and long -term processes of degradation of maize silage in dairy cows. Animal Feed Science and Technology 78: 81-99.

[12] Cone, J.W. and Van Gelder, A.H. (2002). The gas production technique for evaluating ruminant feeds (in Dutch) . In: Workshop of the product Board Animal Feed on Applicability of In vitro Methods to Generate Input Parameters for a Nutrient Based Feed Evaluation System for Dairy Cattle (in Dutch), Lelystad, The Netherlands, pp. 53-68

[13] Dewhurst, R. J., Hepper, D. and Webster, A. J. F. (1995). Comparison in sacco and in vitro techniques for estimating the rate and extent of rumen fermentation of a range of dietary ingredients. Animal Feed Science and Technology, 51:211-229.

[14] Menke, K. H.and Steingass, H. (1988). Estimation of the energetic feed value obtained from chemical analysis and in vitro gas production using rumen fluid. Animal Research and Development. 28: 7-55.

[15] Ørskov, E.R. and McDonald, I. (1979). The estimation of protein degradability in the rumen from incubation measurements weighted according to rate of passage. Journal Agricultural Science (Cambridge) 92: 499-503.

[16] AOAC (2002). Official Methods of Analysis of Official Analytical Chemists (W. Horwtz ed.) $17^{\text {th }}$ Edition, Association of Analytical Chemists, Washington. DC.

[17] Van Soest, P. J., Robertson, J. B. Lewis, B. (1991). Methods for dietary fibre, neutral detergent fibre, and nonstarch polysaccharides in relation to animal nutrition. Journal Dairy Scieince 74, 3583-3597.

[18] Statistical Analysis System Institute Inc.(1988) SASSTAT programme, Cary, NC: SASInstitute Inc. 1988.

[19] Norton, B.W. (2003). The Nutritive value of tree legumes. http://www.fao.org/ag/AGPC/doc/Publicat/Gutt-shel/x5556e0j.htm.pp.110

[20] Norton, B.W. (1998). The nutritive value of tree legumes. In: Gutteridge, R.C., Shelton, H.M. (Eds.), Forage trees legumes in Tropical Agriculture. Tropical Grassland Society of Australia Inc., St Lucia Queensland.

[21] Le Houerou, H.N. (1980) Chemical composition and nutritive value of browse in West Africa. In: Le Houerou, H.N. (ed.), Browse in Africa. ILCA, Addis Ababa, Ethiopia, pp. 261-290.

[22] Rittner, U. and Reed, J. D. (1992). Phenolics and in vitro degradability of protein and fiber in West African browse. Journal of the Science of Food and Agriculture 58, 21-28.

[23] Breman, H. and Kessler, J.J. (1995). Woody Plants in Agro-Ecosystems of Semi-Arid Regions. Advanced series in agricultural sciences no. 23. Springer Verlag, Berlin, Germany, 340pp.

[24] Fall, S.T. (1993). Valeur nutritive des fourrages ligneux. Leur rôle dans la complementation des fourrages pauvres des milieux tropicaux. Thesis Doct. Univ. Sci. Tech. ENSAM, Montpellier, France, 143 pp.

[25] Njidda, A. A., Ikhimioya, I. and Aliyu, I. (2008). Nutritive evaluation of some browsable trees and shrubs leaves from semi-arid region of Nigeria. Journal Arid Agricultural 18: 21-27.

[26] Njidda, A A. (2011). Evaluation of the potential nutritive value of browse forages of semi-arid region of Nigeria. Ph D Thesis submitted to the Department of Animal Science, Ambrose Alli University, Ekpoma Nigeria. 282pp

[27] Meissner, H. H., Viljoen, M. D. and Van Nierkeki, W. A. (1991). Intake and digestibility by sheep of Anthephora, Panicum, Rhode and Smuts finger grass pastures: Proceeding of the IVth International Rangeland Congress, September1991. Montipellier, France, pp 648-649.

[28] Boudet, A.M. (1998). A new view of lignification. Trends in Plant Science, 3, 67-71.

[29] Reed, J.D. (1986). Relationships among soluble phenolics, insoluble proanthocyanidins and fiber in East African browse species. Journal of Range Management 39, 5-7.

[30] Bakshi, M. P. S. and Wadhwa, M. (2004). Evaluation of forest leaves of semi-hilly arid region as livestock feed. Asian-Australasian. Journal of Animal Sciences. 95: 93- 104.

[31] Min, B.R., Barry, T.N., Attwood, G.T., McNabb, W.C. (2003).The effect of condensed tannins on the nutrition and health of ruminants fed fresh temperate forages: a review. Animal Feed Science and Technology 106: 3-19

[32] Barry, T. N. and Duncan, S. J. (1984). The role of condensed tannins in the nutritional value of Lotus pedunculatus for sheep. 1. Voluntary intake. Journal Association Official Analytical Chemist 65: 496-497.

[33] Karshi, M. A. and Russell, J. B. (2001). Effects of some dietary factors on ruminal microbial protein synthesis. Turkish Journal of Veterinary and Animal Science 25: 681-686.

[34] Arieli, A., Mabjeesh, S.J., Shabi, Z., Bruckental, L, Aharoni, Y., Zamwel, S. and Tagari, H. (1998). In situ assessment of degradability of organic matter in the rumen of dairy cows. Journal Dairy Science 81: 1985-1990.

[35] NRC. (2001). Nutrient requirements of dairy cattle, 7th revised ed. Washington, D.C.

[36] Beever, D.E. and Cottril, B.R. (1994). Protein systems for feeding ruminant livestock: a European assessment. Journal of Dairy science, 77:2031-2043.

[37] Arigbede, O.M., Bamikole, M.A., Olanite, J.A., Jalaosho, A.O. and Onifade, O.S.(2002). Seasonal degradability of dry matter, organic matter and crude protein in some multipurpose tree species by West African Dwarf goats. In: Proceedings of the 27' Annual Conference of the Nigerian Society for Animal Production, March 17-21, Federal University of Technology, Akure, Nigeria. Pp 191194.

[38] Kibon, A and Ørskov, E.R (1993). The use of degradation characteristic of browse plants to predict intake and digestibility of goats. Animal Production 57: 247-251.

[39] Nocek, J.E and Russell J.B (1988). Protein and energy as an integrated system: relationship of ruminal protein and carbohydrates availability to microbial: synthesis and milk production. Journal of Dairy Science 71:207-210.

[40] Cerrillo, M. A. and Juárez, R. A. S. (2004) In vitro gas production parameters in cacti and tree species commonly consumed by grazing goats in a semiarid region of North Mexico. Livestock Research Rural Devevelopment.16, Art.\#21. http://www.lrrd.org/lrrd16/4/cerr16021.htm

[41] Njidda, A A. and I. Ikhimioya (2010). Correlation between chemical composition and in vitro dry matter of leaves of semi-arid browses of North-eastern Nigeria. American-Eurasian Journal of Agriculture and Environmental Science 9 (2): 169-175.

[42] Salem, A.Z.M., (2005). Impact of season of harvest on in vitro gas production and drymatter degradability of Acacia saligna leaves with inoculum from three ruminant species.Animal Feed Science and Technology. 123-124, 67-79.

[43] Chikagwa-Malunga, S.K., Adesogan, A.T., Salawu, M.B., Szabo, N.J., Littell, R.C., Kim, S.C. and Phatak, S.C., (2009). Nutritional characterization of Mucuna pruiriens. 2. In vitro ruminal fluid fermentability of Mucuna pruriens, Mucuna 1-dopa and soybean meal incubated with or without 1-dopa. Animal Feed science and Technology. 148,

$51-67$. 
[44] McSweeny, C.S., Palmer, B., McNeill, D.M., Krause, D.O., (2001). Microbial interactions with tannins: nutritional consequences for ruminants. Anim. Feed Sci. Technol. 91, 83-93.

[45] Salem, A.Z.M., Gohar, Y.M., El-Adawy, M.M., Salem, M.Z.M., (2004). Growth- inhibitory effect of some antinutritional factors extracted from Acacia saligna leaves on intestinal bacteria activity in sheep. In: Proceedings of the 12th Scientific Conference of the Egyptian Society of Animal Production (ESAP), Mansoura, Egypt, pp. 283300 .

[46] Salem, A.Z.M., Robinson, P.H., El-Adawy, M.M., Hassan, A.A., (2007). In vitro fermentation and microbial protein synthesis of some browse tree leaves with or without addition of polyethylene glycol. Animal Feed Science and Technology. 138, 318-330.

[47] De Boever, J.L., J.M. Aerts, J.M. Vanacker and D.L. De Brabander, (2005). Evaluation of the nutritive value of maize silages using a gas production technique. Animal Feed Science and Technology, 123-124, 255.

[48] Nordheim-Viken, H., Volden, H., (2009). Effect of maturity stage, nitrogen fertilization and seasonal variation on ruminal degradation characteristics of neutral detergent fibre in timothy (Phleum pratense L.). Animal Feed Science Technology 149, 3059.

[49] Camacho, L. M., Rojoa, R., Salema, A.Z.M., Mendozac, G.D., Lópeza, D., Tinocoa, J.L., Albarrána, B., Monta nez-Valdezd, O.D.(2010). In vitro ruminal fermentation kinetics and energy utilization of three Mexican tree fodder species during the rainy and dry period. Animal Feed Science and Technology. 160: 110-120

[50] McAllister, T.A., Bae, H.D., Jones, G.A., Cheng, K.J., (1994). Microbial attachment and feed digestion in the rumen. Journal of Animal Science 72, 3004-3018.

[51] Steingass, H. and K.H. Menke, (1986). Schatzung des energetischen Futterwertes aus der in vitro mit Pansensaft “bestimmten Gasbildung und der chemischen Analyse.Tierernahrung, 14, 251.

[52] Deaville, E.R. and D.I Givens, (2001). Use of automated gas production technique todetermine the fermentation kinetics of carbohydrate fractions in maize silage. Animal Feed Science and Technology, 93, 205.

[53] Wolin, M. J. (1960). A theoretical rumen fermentation balance. Journal of Dairy Science 43, 1452-1459.

[54] Dynes, R.A.and Schlink, A.C., (2002). Livestock potential of Australian species of Acacia. Conservation Science of Western Australia 4, 117-124.

[55] Tefera, S., Mlamboa, V., Dlamini, B.J., Dlamini, A.M., Koralagama, K.D.N., Mould, F.L., (2008). Chemical composition and in vitro ruminal fermentation of common tree forages in the semi-arid rangelands of Swaziland. Animal Feed Science and Technology $142,99-110$

[56] Ghisalberti, E.L., (1994). The ethnopharmacology and phytochemistry of Eremophila species (Myoporaceae). Journal of Ethnopharmacology. 44, 1-9.

[57] Khazaal K, Dentino, M. T., Ribeiro, J. M and Orskov, E. R (1995). Prediction of apparent digestibility and voluntary intake of hays fed to sheep: comparison between using fibre components, in vitro digestibility or characteristics of gas production or nylon bag degradation. Animal Science 61, 527-538 